\title{
Tolerance Education As Social Reconciliation Means
}

\author{
I Ketut Sudarsana ${ }^{1}$, I Made Arsa Wiguna ${ }^{2}$, Tati Sri Uswati ${ }^{3}$, Samsiarni ${ }^{4}$, Indriani Nisja ${ }^{5}$, Rina \\ Sartika $^{6}$, Lira Hayu Afdetis Mana ${ }^{7}$, Indra Syahputra Marpaung ${ }^{8}$, Parlindungan Siregar ${ }^{9}$ \\ \{liketutsudarsana@uhnsugriwa.ac.id\} \\ ${ }^{1,2}$ Universitas Hindu Negeri I Gusti Bagus Sugriwa Denpasar, Bali, Indonesia, ${ }^{3}$ Institut Agama Islam \\ Negeri Syekh Nurjati Cirebon, Indonesia, ${ }^{4,5,6,7}$ STKIP PGRI Sumatera Barat, Indonesia, ${ }^{8}$ Faculty of \\ Social and Political Science, Universitas Graha Nusantara Padangsidimpuan, Indonesia, ${ }^{9}$ Faculty of \\ Education and Teaching Training, Universitas Graha Nusantara Padangsidimpuan, Indonesia
}

\begin{abstract}
Tolerance education as a vehicle for social reconciliation are forms of uniformity, then through tolerance education learners are invited to live the atmosphere of diversity, so that an inclusive and communicative atmosphere will feel each other. Through education tolerant, tense and full of conflict situations will be directed to the empathetic and inclusive attitude towards plurality uphold social integration and reconciliation, narrow spirit of provincialism, tribalism and sectarian. The role and function of tolerance education is directing or encouraging learners have positive feelings, develop self-concept, elaborated tolerance and accepting others. In addition, the arena seeks to create a culture of learning in a group not only in the scope of the school but also at home and social environment. As a human purpose and result of a democratic Indonesia.
\end{abstract}

Keywords: Tolerance Education; Social Reconciliation

\section{Introduction}

Humans are beings who struggle intensely with education. That is why humans are dubbed as animal educandum and animal educandus at once, namely as educated creatures and educating creatures. In other words, humans are creatures who are always involved in the educational process, both those carried out against others and themselves. In this sense, the United Nations Educational, Scientific and Cultural Organization (UNESCO) as an International Agency that struggles with various problems of education and culture proclaims the concept of "Lifelong Education" which has been going on since the cradle to the grave [1].

Education as a human effort is the best aspect and result of culture that can be provided by every human generation for the benefit of the young generation to continue their life and way of life in the socio-cultural context. Therefore, every pluralistic society in modern times always prepares its elected citizens as education for the sake of the regeneration of each community concerned. On that side, education is needed, which transcends the rules in the family to improve the dignity and personality of individuals to become smarter people.

Based on the above understanding, it can be said that the problem of education is a complex process because it requires the fabrication of theoretical ideas as a basis for decision making in education and understanding of various factual and actual symptoms that involve the discussion of various elements directly related to the educational process [2] [3]. 
Therefore, many elements related to education, it is not ridiculous if in the process of education in general, and learning in particular, various problems often arise. These problems can arise from the mistakes of the education actors themselves or they may also arise because the time is so fast that goes hand in hand with the challenges of the times that are different from the previous times.

With the progress of the times and the challenges that are increasingly rapid as it is today, teachers ideally continue to learn, be creative in developing themselves, and constantly adjust their knowledge and teaching methods in new discoveries in the world of education, psychology, and science [4] [5].

Thus, understanding various elements and constraints in education can be anticipated. If this is difficult to do, then problems that arise in learning as much as possible are overcome, so that they emerge as simple problems. In short, various problems in education if they cannot be eliminated at all, at least they need to be minimized, so that the problems that arise do not interfere with the achievement of general educational goals, or specific learning objectives.

Based on this situation, then through education regarding tolerance, students are guided to appreciate diversity so that there will be no conflict.

\section{Method}

The method used is a qualitative research method with a phenomenological approach. Data collection techniques in this study include observation, documentation, and interviews. Checking the validity of the data collected using triangulation techniques, namely triangulation of sources by comparing data from interviews with one informant to another and triangulation of techniques using interviews and.

\section{Result and Discussion}

\subsection{Education of Tolerance}

Education begins in the infant family who are not yet independent, then expanded in the neighborhood or surrounding community, preschool institutions, formal schooling and so on where children start from small groups to relatively large groups (macro scope) with education starting from classroom teachers who educate on a micro scale and become a substitute for parents [6].

Education in the next session emerged as a symptom of behavior and human efforts to meet the basic basic needs of survival, part of activities to improve life to be more meaningful or valuable. Symptoms of education arise when a group of individuals wants to fulfill the needs of higher or abstract meanings such as knowledge, values of justice, prosperity, and skills to be free from conditions of deprivation such as poverty, disease, or lack of ability to interact with the surrounding environment [7].

Tolerance is an attitude that does not deviate from one's rules to be able to respect every action that others do in the absence of discrimination against groups that are different or cannot be accepted by the majority in a society. Tolerance can be developed because humans are social beings who need the help of others so that harmony of life can be created. In a society based on Pancasila, especially the First Principle, faith in God according to their 
respective religions and beliefs is absolute. All religions respect humans, therefore all religious people must respect each other.

Thus, the role and function of tolerance education is to direct or encourage students to have positive feelings, develop self-concept, develop tolerance and be willing to accept others. In addition, it seeks to create a learning arena in one cultural group not only in the school but also in the home and social environment. So as to achieve the goal of being a democratic Indonesian man.

\subsection{Elements in Reconciliation}

As a representation of the social space, reconciliation not only brings together those who hate each other, but also according to Lederach is a place where truth, human compassion (mercy), justice, and peace can meet and unite together. Furthermore according to him, a true reconciliation will at least be achieved if it contains the conditions of (1) truth in which there is recognition, transparency, disclosure, and clarification of a truth; (2) the existence of compassion which includes acceptance, forgiveness, support, necessity, and healing; (3) peace in which there are elements of harmony, unity, prosperity, security, and respect, and the last is the existence of conditions (4) justice in which there is an element of equality, restoration of relations on the basis of rights owned by someone, restoring everything in accordance with their rights and obligations, and the restitution or the return of the rights of each individual [8].

In this case, reconciliation includes two important elements, namely reconciliation as a focus and reconciliation as a locus. As a focus, reconciliation can be seen as a perspective that is built and directed in improving / restoring the relational aspects that exist in a conflict. It is almost certain that if a conflict occurs, then the relational building between individuals, between groups, and between parties will be disrupted. Reconciliation related to this can be understood as a perspective that is deliberately built on how to schedule it all. Apart from that as a focus, reconciliation can also be understood as a paradox that tries to bring together existing contradictions, such as how to bring together the negative sides of the impact caused by conflict (hate, anger, revenge, etc.) with the positive sides of a future expectations for all lessons received from a conflict (new hope, enthusiasm for change, etc.). As a locus, we can call reconciliation as a social phenomenon, in which it represents a space or place for the meeting of the conflicting parties. Reconciliation must be proactive in creating creative and innovative opportunities, where the conflicting parties can focus on building their relational relationships to be better and more sustainable. And of course, how to be able to share views, feelings, and experiences between them, with the aim of creating a new thought for the interpretation of their former relationship which is full of violence and the negative side of being a more constructive relationship [8].

\subsection{Tolerance Education as a means of social reconciliation}

If during the New Order period the most prominent forms of uniformity, then through tolerance education students are directed to live the atmosphere of diversity, so that an inclusive and communicative atmosphere will be felt with each other. Through tolerance education, a tense and conflictful situation will be directed to an empathic and inclusive attitude towards plurality that upholds integration and social reconciliation, narrowing the spirit of provincialism, tribalism and sectarianism.

Psychologically, tolerance and empathy education can refine human sensibility, making it aware of its existence as a small part of a larger social and cosmic system [9]. Thus, through tolerance and empathy, humans absorb the feelings and life experiences of others who come from different geopolitical, geocultural and geo-ethnic realms. 


\section{Conclusion}

Tolerance education as a means of social reconciliation is directing or encouraging students to have positive feelings, developing self-concept, developing tolerance and being willing to accept others. In addition, it seeks to create a learning arena in a cultural group that is not only within the school but also in the home and social environment. So as to achieve the goal of being a democratic Indonesian man.

\section{References}

[1] I. K. Sudarsana, "Pemikiran Tokoh Pendidikan Dalam Buku Lifelong Learning: Policies, Practices, And Programs (Perspektif Peningkatan Mutu Pendidikan di Indonesia)," $J$. Penjaminan Mutu, 2016.

[2] U. Tirtarahardja, Pengantar Pendidikan Edisi Revisi. Jakarta: Rineka Cipta, 2005.

[3] D. Siswiyo, "Ilmu pendidikan dalam tantangan," Cakrawala Pendidik., 1996.

[4] H. Usman, "Manajemen teori, praktik dan riset pendidikan," in PT. Remaja Rosdakarya, 2012.

[5] J. Musfah, Manajemen Pendidikan Teori, Kebijakan, dan Praktik. Jakarta: Premadamedia group., 2015.

[6] K. U. Sukardjo, M, Landasan Pendidikan Konsep dan Aplikasinya. Jakarta: PT Rajagrafindo Persada, 2013

[7] M. Sukardjo, Landasan Pendidikan Konsep dan Aplikasinya. Jakarta: Rajawali Pers, 2013.

[8] J. P. Lederach, Building peace: Sustainable reconciliation in divided societies. 1997.

[9] A. Sudrajat, "Mengapa Pendidikan Karakter?," Pendidik. Karakter, 2011. 